\title{
INTERNATIONAL RED AID AND COMINTERN STRATEGY, $1922-1926^{*}$
}

Of the numerous front organizations spawned by the Communist International, none became more widely known or more active than International Red Aid (IRA). Created in 1922, IRA served the Comintern for over twenty years until it was dissolved with its parent in 1943. At its peak (1932-1933) this front attained a membership of over fourteen million, scattered over seventy-three national sections. It claimed to have provided relief and aid for thousands of Communist and non-partisan revolutionaries who were subjected to the persecutions of "bourgeois class justice" and "white terror". From its presses poured a steady stream of propaganda in a dozen languages - handbills, leaflets, pamphlets, books, and periodicals. The Red Aid leadership initiated and conducted protest demonstrations and campaigns on behalf of the most celebrated causes of the 1920's and 1930's: Sacco and Vanzetti, the Scottsboro Boys, Tom Mooney, the Reichstag Fire Trial, Ernst Thälmann, Antonio Gramsci, and the Spanish Civil War.

International Red Aid was most active and most useful to the Comintern after 1926, but the preceding four years were perhaps more crucial in the organization's history. Between 1922 and 1926 the front developed its basic organizational forms and began to refine its various activities, and during these four years the Comintern forged in the heat of controversy the role IRA was to play in its larger strategy. The present article is given to examining this formative period of IRA, the central theme of which was the shift in the purpose of the organization from a relief agency to a channel through which propaganda could be carried to the masses. This central theme might be stated equally well as the evolution of a relationship between International Red Aid and the Comintern in which IRA was ostensibly independent, but actually dependent.

* The author wishes to express his gratitude to the University of Richmond Faculty Committee on Research for the summer grants that helped to defray expenses incurred while working on this article. 
The study of IRA in its first four years also touches on matters of more general significance. In the first place, the bitter rivalries that erupted in the Russian Communist Party upon Lenin's death had their impact on IRA, specifically felt in Zinoviev's efforts to impose his theory of revolution and to use the Comintern and its auxiliaries as a power base. In addition, the controversy that developed over the purpose of IRA arose out of disagreements over the implications of the Comintern's United Front strategy. Examination of this controversy helps to establish exactly what that strategy involved and to determine what the United Front demanded of International Red Aid and, by extension, other auxiliaries.

This article is intended to describe the establishment of International Red Aid as a useful instrument of Comintern agitation and propaganda. Organizational development and structure are noted only as they relate significantly to the definition of purpose and the expansion of activities. However, a brief sketch of the structural outlines of IRA will be helpful in familiarizing the reader with the organization.

The first executive body of IRA was a small Central Bureau of four persons, to which fell the responsibility of setting up the new organization. ${ }^{1}$ The Central Bureau after only three months (December 1922 to March 1923) was expanded to eight members and renamed the Central Committee (CC IRA). During the remainder of 1923 and until July the CC IRA (its membership almost identical to the Central Committee of MOPR USSR, the Soviet section of IRA) conducted the affairs of the organization..$^{2}$ The First International Conference of IRA,

1 G. Geiler, "Osnovnye etapy razvitiia MOPR", in : MOPR-Shkola internatsional" nogo vospitaniia (Moskva, 1933), p. 60. Members of the Central Bureau included Julian Marchlewski (Karski), P. N. Lepeshinsky, Fischer, and Kramarov. Julian Marchlewski (1866-1925) was a leading Polish Communist, especially active in the German and Russian revolutionary movements. Among his revolutionary credentials were his participation in the 1907 London Conference of the RSDLP, his work on Iskra, and his involvement in the Spartakus League with Karl Liebknecht and Rosa Luxemberg. Panteleimon Nikolaevich Lepeshinsky (1868-1944) as a youth was active in Narodnaia Volia; for this he was exiled to Siberia in 1897. There he met Lenin and became one of his supporters. After 1917 he was an organizer of Isparta (Commission for the Study of the History of the Communist Party) and later became director of the Museum of History and the Museum of the Revolution. Efforts to identify Fischer and Kramarov have brought meagre success. Both were members of the Society of Former Political Prisoners and Exiles, and Kramarov was a member of the Russian Communist Party. Both worked in the central apparatus of IRA until the First Conference, but neither was a member of the Executive Committee elected at that time. 2 Ibid., p. 61. In addition to the members of the Central Bureau, the new body included V. S. Mickevičius-Kapsukas, V. P. Kolarov, S. M. Tëmkin, and Wilhelm 
held in Moscow in July 1924, changed the name of the central apparatus to the Executive Committee (EC IRA) and enlarged the body to twenty-eight members, adding several non-Soviet Red Aid leaders. ${ }^{1}$ More representative of the international organization than the Central Committee had been, the new Executive Committee exercised greater effective control, although its designated powers and functions were essentially the same as its predecessor's.

The EC IRA occupied a position analagous to that of the Executive Committee of the Communist International (ECCI). It was the executive body of an international organization over which it exercised dictatorial control. According to various statements on organizational principles (including the Statutes of IRA adopted in 1928), final authority fell to the international congress; but in fact the international meetings of IRA were no more decisive than those of the Comintern (at least after the Third Comintern Congress). In both organizations the congresses merely ratified decisions already made by the central apparatus. After

Budich. Marchlewski was made chairman and Tëmkin Secretary of the CC IRA.

Vintsas Simanovich Mickevičius-Kapsukas (1880-1935), an early leader of the Lithuanian Social-Democratic Party, was one of the founders of the Lithuanian Communist Party in 1918. A supporter of Lenin after 1914, he joined the RSDLP in June 1917, soon after arriving in Petrograd. He was elected to the ECCI as a candidate in 1924 and as a full member in 1928.

Vasil Petrov Kolarov (1887-1950), a leader of Bulgarian socialism, took part in the Zimmerwald Conference of 1915, where he supported Lenin's views. He became a member of the ECCI in 1921, was elected to the Presidium in 1922, and served as general secretary in 1923. Perhaps best known as an agrarian expert in the ECCI, Kolarov was president of the Krestintern from 1928 to 1939. After 1945 he held top positions in the Bulgarian government.

S. M. Tëmkin seems to have been distinguished solely for his work in IRA. He was a member of the central apparatus of both the international organization and its Russian section until 1927.

Wilhelm Budich, about whom little information could be found, was active in the German Communist Party and apparently was one of the founders of the German Red Aid in 1921.

1 Pervaia Mezhdunarodnaia Konferentsiia MOPR, 14-16 iulia 1924g. Stenograficheskii otchet (Moskva, 1924), p. 81. Hereafter cited as Pervaia Konferentsiia. Six of the EC IRA members represented MOPR USSR; one, Mezhrabpom (another Comintern front, centered in Germany); and the rest, sixteen countries, mostly European. Many of those elected would attain no greater prominence in international communism, but some would make their names known. These included Willi Münzenberg, chairman of Mezhrabpom and founder of several other important Comintern fronts; Wilhelm Pieck, leader of the German Communist Party in the later '30's and president of East Germany after World War II; Tomash Dombal', the Polish Communist who founded the Krestintern; and Anselmo Maribini, a leader of Italian Communism. A list of members of the EC IRA is found in MOPR (July-August 1924), p. 38. 
1924 the principle of "democratic centralism" was applied to IRA as to the Comintern; consequently the Executive Committee determined the policies of every section of the international organization. To the EC IRA was given control of every decisive lever of power: it regulated the finances of the national sections and the organization as a whole; it passed on the statutes of national sections; it monitored the work of officials at the national level; it approved or rejected the sections' programs of action; it determined whether a section remained affiliated with IRA. ${ }^{1}$ Because the EC IRA possessed virtually absolute authority, its policy statements and activities, along with those of the Comintern, form the basis of this study.

The first of the following four sections examines the creation of International Red Aid and its activities during 1923, before its potential usefulness was fully recognized by the Comintern. The second section contains a description and analysis of the controversy that developed in 1924 within the Comintern and IRA over the purpose of the auxiliary. The third part presents the resolution of the conflict between rival definitions of purpose. Finally, the activities of the organization are discussed in order to determine the practical means by which IRA attempted to fulfill the expectations of the Comintern.

CREATION AND INITIAL DEVELOPMENT OF INTERNATIONAL RED AID

The first step toward creation of International Red Aid came in August 1922, when the Central Committee of the Polish Communist Party appealed for aid on behalf of alleged victims of bourgeois persecution in Poland. ${ }^{2}$ In response to this appeal the Polish Bureau of the Russian Communist Party formed a Commission to Aid Political Prisoners in Poland, ${ }^{3}$ which was placed under the leadership of Julian Marchlewski, representing the Society of Old Bolsheviks, and Felix Dzer-

10 let MOPR (Moskva, 1932), pp. 40-43. "Democratic centralism" refers to Lenin's theory of Party organization, in which lower units elect higher ones, while higher units exercise absolute authority over the lower. In both theory and practice "democratic centralism" has meant "centralized control exercised by a small party leadership over a well-disciplined rank-and-file membership". Kermit E. McKenzie, Comintern and World Revolution, 1928-1943: The Shaping of Doctrine (London and New York, 1964), p. 96.

2 International Press Correspondence (March 7, 1928), p. 262. Hereafter cited as Inprecor.

${ }^{3}$ Geiler, p. 59. The Polish Bureau of the RCP was composed of Polish Communists living in the Soviet Union. 
zhinski, representing the Society of Former Political Prisoners and Exiles. ${ }^{1}$ On September 13 Marchlewski presented to the Society of Old Bolsheviks in Moscow a resolution to create an international organization of aid to political prisoners in all countries. The organization would be called in Russian Mezhdunarodnaia organizatsiia pomoshchi bortsam revoliutsii (MOPR), usually translated as International Red Aid. ${ }^{2}$ It was formally established on September 29 under the leadership of Marchlewski and P. N. Lepeshinsky. ${ }^{3}$

The Fourth Comintern Congress endorsed the young organization on November 29, 1922, after the Polish Communist Felix Kon had described the newly created body. Noting that all over the world "our comrades, the leaders of the working class", were being imprisoned, Kon declared, "Now is the optimum moment for us to establish a political Red Cross in every country." He maintained that each Communist Party should be responsible for building an organization that would aid revolutionaries persecuted by the bourgeoisie. ${ }^{4}$ The Congress unanimously adopted Kon's brief resolution, which called upon

"all Communist Parties to assist in the creation of organizations to render material and moral aid to all captives of capitalism in prison. The IV Congress welcomes the initiative of the Russian 'Society of Old Bolsheviks' which is trying to create an international union of these organizations." 5

By sanctioning International Red Aid the Comintern ensured the success of the organization and began the process of incorporating it into its strategy.

1 Yelena D. Stasova, Piat' let MOPR i sovremennye ego zadachi (Moskva, 1928), p. 7. Felix Dzerzhinski (1877-1926) participated in both the Polish and Russian revolutionary movements. He was elected to the Central Committee of the RSDLP in 1907. Imprisoned from 1912 to 1917, he was elected to the CC of the Russian Communist Party in August 1917. Dzerzhinski was a close comrade of Lenin and was given the task of organizing and heading the Cheka in December 1917.

2 In Russian materials the initials "MOPR" are usually used for both the Soviet section and the international organization of IRA. Throughout this study "MOPR USSR" will be used to designate the Soviet section. In the United States IRA was known as International Labor Defence and in Great Britain International Class War Prisoners' Aid Society.

3 Stasova, p. 7.

4 Protokoll des vierten Kongresses der Kommunistischen Internationale, Petrograd-Moskau vom 5 November bis 5 Dezember, 1922 (Hamburg, 1923), p. 836. The "political red cross" referred to Krasnyi Krest, an aid organization founded in 1881 by Narodnaia Volia.

'Ibid., p. 837. 
The most notable accomplishment of the Fourth Comintern Congress that endorsed IRA was its adoption of the United Front strategy. Forged in the months after the Third Congress (June-July 1921), the United Front represented a Communist awareness that the revolutionary tide had ebbed and that capitalism was becoming better able to defend itself against revolutions and revolutionaries. Authoritarian governments were being established in Italy, Bulgaria, Hungary, and elsewhere; and in the western democracies - France and Britain conservatism seemed to be entrenched. In addition, the countries of Europe were recovering from post-war depression and economic dislocation and were moving toward the era of prosperity that marked the mid-twenties. Ecconomic recovery had dulled what revolutionary spirit the masses may have had, and the reemergence of political conservatism indicated, ominously for Comintern leaders, that the forces of order were stronger than the forces of disruption. Consequently the United Front strategy meant that the revolution was postponed indefinitely, and that Communists must preserve their cadre and build their strength until a new revolutionary situation appeared.

International Red Aid, created to aid Communist prisoners and emigrants and thereby to keep up their strength for the future revolution, could be expected to fullfill a major demand of the Comintern strategy. To the extent that the United Front was a defensive strategy designed to preserve the Communist movement, IRA was a logical outgrowth. But the United Front was also in part offensive, for it dictated that the Communist movement should strengthen itself by bringing the majority of the unaffiliated and Socialist masses under Communist influence. Toward this end the United Front postulated two alternate approaches for Communists to take in dealing with the non-Communist world. When the strategy was applied "from above", short-term collaboration for specific goals was permitted between Communist and Socialist Parties. When the United Front "from below" was the cry, Communists were to appeal directly to the masses over the heads of the Socialist leadership. Whether the United Front was pursued offensively from "above or "below", organizations such as IRA, formally independent of the Comintern but under its control, were expected to help organize the masses outside the Party and bring them under its influence.

At its founding IRA was considered much more important for its aid to persecuted revolutionaries than for its appeal to the masses; the latter role was not even mentioned at the Fourth Comintern Congress. The need to seek mass support, however, was articulated at the initial meeting of the Central Bureau of IRA, held on December 22, 1922.1 ${ }^{1}$ Geiler, p. 60. 
The resolution issued at that meeting introduced the secondary purpose of "awakening and revealing in active form the international solidarity of the toiling masses", in addition to the primary task of rendering "material, moral, and political aid to revolutionary fighters - victims of the class struggle in all countries of the world". ${ }^{1}$

The two roles to be played by IRA in pursuing the United Front were not altogether compatible. In order to aid incarcerated Communists and other revolutionaries, the organization might best have been a formally designated section of the Comintern perhaps somewhat like the Communist Youth International. If it were openly identified as a Comintern subsidiary, however, IRA would have jeopardized its potential influence over the "toiling masses." Until the Comintern leadership decided in which role IRA would be most useful, the auxiliary attempted to pursue contradictory goals. The contradictions meant little in 1923, but in the following year they sparked a debate crucial to the history of IRA.

Whatever the specific purposes of IRA, a world-wide network of sections was required before its presence would be felt. Steps toward giving the front an international character were taken by the First Plenum of the recently formed Central Committee of IRA on June 26, 1923. ${ }^{2}$ The CC IRA declared that Red Aid organizations must be established in every country, particularly in those in which the "white terror does not hold sway". ${ }^{3}$ It was observed that such countries (Britain, France, and the United States) offered the best opportunity for creating sections, and that these sections should provide the bulk of financial support for the organization as a whole. By this time sections were being formed in eight countries outside the USSR - Bulgaria, Estonia, France, Germany, Italy, Latvia, Lithuania, and Poland. In an effort to consolidate Communist aid activities and the prevent duplication in this work, the Plenum stated that all independent aid organizations, such as the League to Aid German Children, would be absorbed into IRA. 4

While the organizational network was expanding, IRA was starting to dispense the aid for which it was created. By far the most significant activity of IRA during 1923 was the aid it rendered to political pris-

'Felix Kon, "Desiatiletie Kominterna i MOPR", in: Kommunisticheskii Internatsional (March 8, 1929), p. 156. "Toiling masses" usually refers to nonCommunist workers, as opposed to "proletariat", i.e., Communists.

2 Inprecor (August 9, 1923), p. 595. Held in Moscow immediately after the Third Plenum of the ECCI (during which no mention was made of IRA), the CC IRA meeting was attended by delegates of various Communist Parties already in Moscow for the earlier ECCI Plenum.

3 Geiler, p. 61.

Inprecor (August 9, 1923), p. 595. 
oners. Outside the Soviet Union, in fact, this was the only activity undertaken by the organization, according to the ECCI. ${ }^{1}$ The amount of aid distributed cannot be determined accurately, for the various sections allegedly collected and dispensed funds without any accounting to the CC IRA. In addition to any money expended locally and not reported, the CC IRA reported that it spent over one-half its total revenue for the year - 170,000 of 300,000 rubles - on aid to political prisoners in capitalist countries. ${ }^{2}$ Most of the money sent from the Soviet Union for aid to political prisoners abroad was disbursed through the German (42.5\%) and the Bulgarian (28\%) sections. The remainder was parceled among twelve other European countries, China, and Japan. ${ }^{3}$ Germany and Bulgaria were, of course, the states in which the Communists made abortive attempts at revolution during the autumn of 1923. It would not be surprising to learn that IRA had helped to channel Soviet funds to the unsuccessful insurrections, but firm evidence is lacking. ${ }^{4}$

IRA also began on a very small scale to develop its potential as a vehicle of Communist agitation and propaganda (agitprop). Aside from an inconsequential amount of published propaganda, ${ }^{5}$ the bulk of Red Aid agitprop was related to the various commemorative days celebrated by the Comintern. The revolutionary anniversary with which IRA became most closely connected was March 18, the founding date of the Paris Commune in 1871. The Fourth Comintern Congress had already designated March 18 to be an annual "Day of Aid to Revolutionary Fighters", an idea congenial to IRA, even though the date was not at that time linked with the organization. ${ }^{6}$ The Central Bureau on January 12, 1923, suggested that IRA adopt March 18 as its annual day, ${ }^{7}$ and it issued a circular dictating that this "International

1 From the Fourth to the Fifth World Congress. Report of the Executive Committee of the Communist International (London, 1924), p. 99.

2 Pervaia Konferentsiia, p. 31. The failure of some sections to report all expenditures may be viewed as indicating how little effective control the central apparatus exercised over the international organization before 1924 .

3 MOPR (March-April, 1924), p. 35.

4 Angelo Tasca (pseud., A. Rossi) states in A Communist Party in Action (New Haven, 1949), p. 190, that "MOPR served as a channel for financial aid to Communist Parties" from Moscow.

5 Geiler, p. 61 . Only one periodical was published before 1924, the journal MOPR, and none of the issues for 1923 could be located. Almost all published IRA agitprop appeared in Comintern periodicals, primarily Inprecor.

- M. Kushner, Materialy po MOPR; Spravochnaia kniga dlia otdelenii, iacheek, i aktivnykh rabotnikov MOPR'a (Moskva, 1925), p. 166. The Paris Commune has been lauded by Communists, none too accurately, as the first example of a government of, by, and for the proletariat.

7 Geiler, p. 61. 
Relief Action [...] must be prepared and carried through in good co-operation by all Red Aid organizations in a united fashion."1 The circular outlined four basic aims to be sought in the March 18 campaign. These four aims, which summarized the objectives of IRA agitation and propaganda for years to come, included the following: 1) to win the sympathies of the broad masses for imprisoned revolutionary fighters, 2) to intensify the fight for the amnesty of "our percuted revolutionaries", 3) to increase the collection of aid for political prisoners and their families, and 4) "to give moral strength and relief to our prisoners". ${ }^{2}$ After 1923 the founding day of the Paris Commune was consistently indentified as the Day of IRA and was celebrated as the organization's first and most important annual campaign.

By the end of 1923 International Red Aid was a well-established Comintern auxiliary. The most ambitious of all "proletarian relief" organizations founded since the mid-nineteenth century, it had begun to form a network of sections that would eventually extend to seventythree countries. IRA was not yet an overwhelmingly effective dispenser of aid, although 170,000 rubles (about $\$ 86,000$ ) spent on relief was a creditable beginning. But the organization had thus far operated within a rather narrow sphere; the full potential of its usefulness to Comintern strategy was still unrealized. In its first year, as the ECCI observed, IRA had followed a severely limited course in confining its activities to aiding political prisoners. During the next two and a half years a broader definition of IRA tasks would be worked out amid larger controversies within the Russian Communist Party and the Comintern.

\section{II}

THE CONFLICT OVER THE PURPOSE OF IRA

The possibility of a conflict over the purpose of International Red Aid appeared late in 1922 , but only in the early months of 1924 did the possibility become reality. Once the debate had begun, however, it continued until the Sixth Plenum of the ECCI in 1926. The issue of controversy was whether IRA should be a narrowly Communist aid organization or a broader, "non-party" agitational and organizational weapon of the United Front. The outcome of the debate over the aims of IRA determined the nature of the organization and its activities at least until 1935. The course of the debate was significant because it

10 let MOPR, p. 107.

2 Ibid. 
was conducted on the periphery of the struggle for power within the Soviet Union in the aftermath of Lenin's death in January 1924. Grigori Zinoviev, one of the major contenders, precipitated the IRA controversy when he used the organization as a medium through which he expressed his theories of revolution.

The debate over the purpose of IRA was opened by Zinoviev, the Comintern chairman, when he spoke on January 30, 1924, to an AllUnion Conference of MOPR USSR. In his speech Zinoviev noted the ebb of revolutionary opportunity in Europe and predicted a deepening wave of "white terror". Then he turned to the duties of IRA. In those countries where the "white terror" raged, IRA was charged to give relief to persecuted revolutionaries and to help rebuild Communist organizations disrupted by the bourgeoisie. To illustrate the magnitude of the task, Zinoviev cited examples of "white terror". In Germany, "thousands of worker-Communists are left without a crust of bread because they are Communists." In Yugoslavia severe repression had forced the Party underground. Similar pictures were drawn of the situations in Japan, Bulgaria, and Italy. ${ }^{1}$ Zinoviev also suggested that in contries where the class struggle was not severe, as in the United States, IRA should provide an organizational structure to parallel weak Communist Parties and to help strengthen them. ${ }^{2}$

Zinoviev emphasized more than had been done previously the importance of Party support for IRA. Acknowledging that the Party had done little to help the development of the organization, he pledged "greater diligence" in the future. In addition, he promised that "the ECCI and the CC of the Parties must give and will give every support to further the work of IRA." His general appraisal of IRA was unequivocal: it was "one of the greatest organizations in support of the international revolutionary movement". 3

Zinoviev expected IRA to benefit the Communist movement in two ways. First, the aid given incarcerated revolutionaries would enable them to survive the temporary recovery of capitalism and to conserve their strength for the later revolution. In the second place, IRA seems to have been considered an organizational alternative to the Party wherever Communists were weak or subjected to repression. Zinoviev thus considered International Red Aid to be a defensive organization, designed to protect the Communist movement from the onslaughts of a recovering capitalist world.

The ECCI presented a different interpretation in a report issued on

\footnotetext{
1 MOPR (March-April, 1924), p. 31.

Ibid., p. 30.

${ }^{3}$ Ibid.
} 
the eve of the Fifth Comintern Congress. ${ }^{1}$ Appearing in the spring of 1924 , the report summarized the activities of the various organizations of the Comintern during the eighteen months since the Fourth Congress, and it included a rather lengthy section devoted to the activities and prospects of International Red Aid. ${ }^{2}$ Evaluating the international situation, the ECCI reiterated Zinoviev's comments to the MOPR USSR Conference; an increase in "white terror" was predicted as capitalist states resorted to the most vicious methods of repression against the working class. The report did not agree with Zinoviev, however, in explaining the tasks of International Red Aid. In countries with severe reaction, the ECCI reasoned, a natural solidarity was engendered in the workers and peasants; IRA was therefore not urgently needed in such countries. "IN ALL COUNTRIES WHERE THE WHITE TERROR IS NOT SO STRONGLY ENTRENCHED, THE WORKERS AND PEASANTS MUST BE DRAWN INTO THE WORK OF INTERNATIONAL RED AID BY CONTINUOUS PROPAGANDA." "3 The ECCI was here describing IRA as an offensive weapon of the United Front, to be used in the effort to win the sympathies of the unaffiliated masses.

The ECCI in its report implied that International Red Aid should be an instrument of the United Front "from below", the strategy to which the Comintern would shift at its Fifth Congress (June-July 1924). The policy of United Front "from above", calling for temporary Communist alliance with Social-Democratic parties, had been called into question when the Saxony uprising of October 1923 failed at least partly because the Social-Democratic leadership refused to support the

1 Unfortunately, there is no record of discussion concerning IRA within the ECCI and consequently it is not possible precisely to identify Zinoviev's opponents. It is likely, however, that Karl Radek, Klara Zetkin, and Nikolai Bukharin were among those seeking a broader role for IRA. At the 1923 Plenum of the ECCI Zinoviev emphasized the need to consolidate existing parties and organizations, whereas Radek, Zetkin, and Bukharin called for efforts to broaden the mass base of support.

${ }^{2}$ From the Fourth to the Fifth World Congress, pp. 98-100. The report also presented a lengthy chart running several pages which showed what questions had been considered by leading Comintern organs (the ECCI, Presidium, Secretariat, and Orgburo) in the year and a half since the Fourth Congress. The question of IRA had been discussed by the bodies a total of fifty-three times (only five items out of several dozen appeared more frequently), and within the Secretariat IRA ranked third as a subject on the agenda (ibid., p. 118). These figures do not, of course, suggest how significant were the fifty-three discussions of IRA, but they would seem to indicate that the development of IRA was indeed a matter of considerable and recurring concern to the Comintern leadership.

3 Ibid., p. 100. Capitals in the original. 
Communist initiative. As a result the Fifth Congress required that, except in special circumstances, the United Front strategy was henceforth to be applied "from below". Instead of alliance with Socialist leaders, Communists were now to appeal directly to the SocialDemocratic rank-and-file, seeking to bring them under Communist influence while attacking their leaders. The new interpretation of the United Front directly affected the character of IRA. So long as IRA was presented in narrowly sectarian terms (i.e., Zinoviev's interpretation), it would have little appeal to the non-Communist masses. As a seemingly non-partisan organization disseminating propaganda and enlisting the masses in its ranks, however, IRA was made to order for the United Front "from below".

The Fifth Comintern Congress left no doubt that IRA was considered valuable primarily for its appeal to the masses. Its "Resolution on International Red Aid" (the only resolution on a front organization adopted by the Fifth Congress) called IRA "one of the most important weapons of the United Front", constantly enveloping "new forces in international solidarity" and drawing the masses "directly into the revolutionary struggle of the proletariat". Working for Comintern goals behind a non-partisan facade, IRA was expected to unite "large masses of workers and peasants without distinction of party affiliation. ${ }^{1}$

Nothing in the resolution of the Fifth Congress suggested, as Zinoviev had done in January, that IRA should prop up weak Party organizations. Yet the conflict between the front's alternative purposes was not resolved, for the Congress did not entirely repudiate the defensive interpretation. It was noted that the aid sent to imprisoned and exiled revolutionaries would help sustain the cadre of experienced fighters until the revolution was once more at hand. Furthermore, the Congress considered it essential that Communist Parties help enlarge and strengthen IRA, and it specified three ways in which they were to work toward this end:

1. Communist Parties must in every way support IRA and promote the creation of IRA organizations, sections, and branches in their countries, while urging their members to take active part in Red Aid work and to pay regular dues.

2. The Party press must devote the greatest attention to agitation and propaganda for aid to revolutionary fighters.

3. ... attention to IRA must be given in all Party campaigns. ${ }^{2}$

The resolution also confirmed March 18 as the Day of IRA and noted

1 Piatyi vsemirnyi kongress Kommunisticheskogo Internatsionala, 17 iiunia-8 iiulia, 1924g. ; stenograficheskii otchet (Moskva, 1925), pp. 983-984.

2 Ibid., p. 983. 
that all sections of the Comintern were to participate in its celebration. ${ }^{1}$ The Fifth Comintern Congress apparently held International Red Aid in rather high regard; it certainly gave the front a far stronger endorsement than the Fourth Congress had done.

Despite the differences in emphasis, Zinoviev and the Fifth Congress agreed that IRA was a valuable auxiliary to the Communist movement, and perhaps the debate over purpose would never have occurred if IRA had not been considered important. The Red Aid press in the spring of 1924 enthusiastically seized upon the evidence of increased Comintern support for IRA and paid little heed to the discussion over the organization's purpose. The resolution of the Congress was cited to demonstrate the Comintern's heightened interest in the front, and the call for increased Party support was especially praised. Zinoviev's comments at the All-Union Conference of MOPR were said to have obligated "the ECCI itself [...] to stand beside the fulfillment of IRA". ${ }^{2}$

After Zinoviev, the ECCI, and the Comintern Congress had each defined the objectives of the front, the leadership of International Red Aid gave its views at the First International Conference of IRA, held in Moscow on July 14-16, 1924. In all the statements made at this Conference the offensive interpretation emphasized by the Fifth Comintern Congress prevailed. No one suggested, as Zinoviev had done, that IRA was to provide a substitute organization where the Party was weak, or even that the primary task of IRA was to render aid. Although Zinoviev's position was criticized obliquely, it was not explicitly disavowed by any Red Aid spokesman. In general the speakers played down contradictions by considering the purpose of IRA to consist of aid and propaganda in equal parts.

The balanced tone that characterized the discussion of purpose at the Red Aid Conference was set by the first speaker to address himself to this question. Speaking on the opening day, V. P. Kolarov, representing the Bulgarian Communist Party, asked rhetorically, "We have the Comintern; we have the Communist Youth International; why do we need a new international, why our new international organization IRA?"3 His answer was that "the vanguard of the most advanced fighters" for world revolution could not succeed unless the broad masses were mobilized behind them. The cardinal purpose of IRA was therefore "to draw the entire worker and peasant mass, if not into the front ranks, into the legions of international revolution, into the ranks of the army." In addition IRA was to provide needed support for "our

1 Ibid., p. 984.

2 MOPR (May-June, 1924), p. 3.

3 Pervaia konferentsiia, p. 17. 
advanced troops" (i.e., Communists) by sending aid to imprisoned revolutionaries. ${ }^{1}$ These two duties - primarily to enlist the sympathies of the masses and secondarily to support the revolutionary movement with aid for persecuted comrades - made up the IRA interpretation of its role in the Communist movement. This viewpoint differed in no essential respect from that expressed at the Fifth Comintern Congress.

The speaker who came closest to an explicit repudiation of the Zinoviev position was Israel Amter, who reported on the activities of the CC IRA." Amter criticized "those comrades" who declared that IRA existed merely to collect money and render aid. The larger purpose of IRA, he asserted, was political, in that the organization was to enlist and influence the broad masses. ${ }^{3}$ Amter stated unequivocally that "IRA is not a Communist organization"; but he also stressed the necessity for Party support. Noting that "IRA is an organization of the United Front", he complained that the Party had not yet realized "the political importance" of Red Aid work, i.e., the utility of IRA in the United Front "from below".4

A compromise approach was offered by the other speaker representing the CC IRA, Stanislaw Pestkowski. ${ }^{5}$ He suggested that the purpose of IRA should vary, depending on the political situation from country to country. Where repression and reaction claimed victims from among the revolutionary cadre, IRA should play a defensive role by aiding those victims. ${ }^{6}$ Where the political situation was more liberal and the socialist parties strong, however, IRA should go on the attack as "an instrument of the United Front", seeking to organize the masses.?

The Resolution on the Reports of the CC IRA combined the positions of Amter, Kolarov, and the Fifth Comintern Congress into the official policy of the organization. The aim of IRA was stated to be the creation of "mass organizations by attracting into the ranks of IRA the broad non-party masses of workers and peasants". 8 At no point in the

1 Ibid., pp. 17-18.

2 Israel Amter was a member of the American Communist Party especially active in the state of New York. He was never listed as a member of the IRA apparatus, and after the Conference he seems to have had no direct connection with the organization. There was given no explanation of why he was designated to report on the work of the CC IRA.

3 Pervaia konferentsiia, p. 37.

4 Ibid., p. 39.

5 Pestkowsky was a Polish Communist and a member of the Society of Former Political Prisoners and Exiles. It is not clear when he entered the central apparatus of IRA. He was first mentioned in Red Aid literature in the spring of 1924.

6 Pervaia konferentsiia, p. 29.

7 Ibid., p. 32.

8 Ibid., p. 92. 
resolution were the aid activities of IRA even mentioned in connection with aims or purposes.

It might appear that the Comintern and IRA meetings had decided that International Red Aid should serve the United Front strategy both offensively and defensively, and that Zinoviev's exclusively defensive definition had been rejected. Such, however, was not the case. The Comintern chief had not abandoned his intention to press upon IRA his interpretation of its role in international Communism, and the conference's selection of Red Aid leadership apparently reflected his influence. Neither Kolarov nor Amter, the two speakers at the Conference whose views most differed from Zinoviev's, were among the twenty-eight persons elected to the newly created Executive Committee (EC IRA); Pestkowski, who had offered a compromise position, was included in the central apparatus. Furthermore, only two of the original eight members of the CC IRA were carried over into the new Executive Committee; these were S. M. Tëmkin, the secretary of both bodies and P. N. Lepeshinsky. A turnover of major proportions was effected in the leadership of IRA. ${ }^{1}$

The most significant evidence linking the change of leadership to Zinoviev was the election of Albert Treint as chairman of the EC IRA. ${ }^{2}$ Chief of the French Communist Party and secretary of the ECCI, Treint was well known to be a sympathizer and ally of Zinoviev and a vigorous opponent of the Trotskyists. He had not been linked with IRA before the July Conference, which, incidentally, he apparently did not attend. Treint's influence over International Red Aid was not great. Only rarely did his name appear in the Red Aid press after he entered the Executive Committee, and no changes in policy or activities could be clearly attributed to his influence. After being expelled in 1926 from the French Party and the Comintern for his identification with and support of Zinoviev, Treint was replaced as Chairman of the EC IRA by Lepeshinsky, the ranking member of the Soviet delegation to the Executive. ${ }^{3}$ The change was not even mentioned in the IRA press. Treint's name did not appear after 1927 in IRA publications, and later sketches of the history of IRA omitted all reference to him.

It might be argued that Treint was made charman in order to elevate the status of IRA in the eyes of foreign Communist Party leaders. More likely he was given the post through the influence of Zinoviev, who was attempting to establish in the Comintern and its auxiliaries a firm base

1 Members of the EC IRA are listed in MOPR (July-August, 1924), p. 38.

2 Pervaia konferentsiia, p. 107.

3 Biulleten' Tsk MOPR SSSR (January 31, 1927), p. 3. Hereafter cited as Biulleten'. 
of operations that would help him to take over the position of leadership left vacant by Lenin's death. However, after the Central Committee of the Russian Party condemned Trotsky in January 1925, Zinoviev found himself thrown increasingly on the defensive by the growing power of Stalin. Treint's lack of influence within IRA very likely resulted from the deteriorating situation of his mentor, Zinoviev, within the Russian Communist Party and the Comintern.

By mid-summer of 1924 the main lines of the conflict over the purpose of International Red Aid had been drawn. The International Conference of IRA illustrated, however, that this was still a rather muted controversy involving differences of emphasis more than of fundamental principles. During the remainder of 1924 after the Red Aid Conference the debate over purpose either was dormant or was being conducted behind the scenes.

\section{III}

\section{INTENSIFICATION AND RESOLUTION OF THE CONFLICT OVER PURPOSE}

The question of how International Red Aid could most effectively serve the Comintern once again became an issue in March 1925. And again Zinoviev was responsible for arousing the controversy, this time when he spoke to the First All-Union Congress of MOPR USSR (March 17-18). ${ }^{1}$ The Comintern Chief strengthened and enlarged upon his earlier position that IRA was exclusively a Communist organization of aid to Communists. Zinoviev made his position more explicit almost certainly because of the growing tension between him and his rivals (especially Stalin) within the Russian Party. After Trotsky had been defeated in January 1925, Zinoviev was soon made aware that he now faced an extremely dangerous enemy in his erstwhile ally, Stalin. Realizing his disadvantageous situation, he made the MOPR USSR Congress a forum for his theories while he curried the organization's support.

Zinoviev's speech to the MOPR USSR Congress summarized his philosophy of revolution, which was to be condemned as "ultraleftist" in 1927. This philosophy amounted to a rejection of the United Front strategy in any form. Zinoviev opposed all compromise, however limited, with non-Communist parties, fearing that the revolutionary purity of Communists would be corrupted. At the same time, he tended to play down the necessity of winning mass support for Communism, suggesting instead that this support would fall into place automatically

1 The meeting held on January 30-31, 1924, was called a Conference (Konferentsiia), while the assembly of March 1925 was a Congress $\left(S^{\prime \prime} e z d\right)$. 
when the revolutionary struggle began. ${ }^{1}$

Zinoviev interpreted the utility of IRA to the Communist movement in terms of his philosophy of revolution, and his interpretation in 1925 was more extreme than previously. He held that IRA must devote its energies almost exclusively to providing "aid to revolutionary workers of the whole world persecuted by the bourgeoisie." Advocating that IRA be no more than a branch of the Comintern, Zinoviev concluded his speech by saying,

"IRA is a Communist Organization... It is one of the sections (zven'ev) of the international proletarian movement. The ECCI knows that IRA is one of its sections and even one of its most important sections." 2

No other figure connected with International Red Air or the Comintern was ever quoted in print so explicitly starting the relation of IRA to its parent organization. If IRA had officially endorsed this candid appraisal of its subordination to the Comintern, its potential effectiveness in "mobilizing the broad masses in the spirit of international solidarity" would have been severy impaired. But Zinoviev was apparently unconcerned with the mass appeal of IRA, for nowhere in his speech did he suggest that IRA should attempt to win the support of nonCommunists.

Zinoviev's defensive, sectarian conception of IRA was not accepted by the Red Aid central apparatus, even at the Congress that he addressed. The spokesman for the EC IRA at the Congress was V. P. Kolarov, whose presence in this capacity was an implicit rejection of Zinoviev's position since he had not supported Zinoviev at the IRA Conference in July 1924, and, more importantly, had become identified with Stalin. Kolarov did discuss the necessity of aiding revolutionary fighters, and he urged that the Party give increased support to IRA. When he defined the purpose of the organization, however, he declared its "most important task" to be the "mobilization of the broadest masses under the banner of international solidarity". ${ }^{3}$ Kolarov did not attack the statements of Zinoviev; he simply ignored them.

${ }^{1}$ See William Korey, Zinoviev on the Problem of World Revolution, 1919-1927 (Ph.D. dissertation, Columbia University, 1960), passim.

2 Pervaia vsesoiusnyi s"ezd MOPR, 15-18 marta 1925g. Stenografisheskii otchet (Moskva, 1925), p. 28. Hereafter cited as Vsesoiuznyi s"ezd. In 1935 after overtures had been made to the Socialist International seeking its co-operation with IRA, the above quotation was repudiated on the grounds that it had been made by "a former chairman of the C. I. and a renegade Communist". Internatsional'nyi Maiak (March, 1935), p. 4.

8 Vsesoiuznyi s"ezd, pp. 32-33. 
After the MOPR USSR Congress the matter of determining what the Comintern expected of International Red Aid was taken over by the Executive Committee of the Communist International in the Fifth and Sixth Plenums of the ECCI (March 21-April 6, 1925, and February 17-March 15, 1926, respectively). These two meetings of the Comintern leadership exercised more influence over the policies and activities of IRA than any others between the Fourth and the Seventh Comintern Congresses.

The Fifth Plenum adopted a resolution devoted specifically to the question of IRA and its place in Comintern strategy. The resolution stressed the importance of IRA in the face of intensifying "white terror", growing fascism, and deepening class struggle; and it included among the responsibilities of IRA in this situation both the influence it was to extend over non-Communists and the aid it was to give revolutionary fighters. The Plenum placed itself firmly in support of the offensive interpretation of IRA by emphasizing the mass influence of the organization far more than the aid it rendered. ${ }^{1}$ The ECCI declared that International Red Aid should become a "truly mass, non-party, public organization", the purpose of which was to involve the "toiling masses" in the revolutionary movement. IRA was to be "an elementary school to educate the masses in the spirit of international proletarian solidarity". ${ }^{2}$ Its usefulness to the Comintern would be twofold. First, it would through agitation and propaganda either neutralize the unaffiliated masses or gain their active support. Second, it would provide "a reserve from which the Communist Party may be replenished", acting as a sort of clearing house for potential Party members. ${ }^{3}$

Thus the Fifth Plenum of the ECCI ended the debate over the purpose of IRA by rejecting almost completely Zinovieve's defensive interpretation. International Red Aid was no longer to be considered a Communist organization, but rather an independent class organization only incidentally supported by Communists. From Zinoviev's point of view his defeat over the use to be made of IRA was hardly decisive in his fight against Stalin, but his implicit repudiation in this matter by the ECCI carried ominous overtones for the Comintern chairman. To International Red Aid, on the other hand, the resolution of the controversy was of crucial importance, for the Fifth Plenum firmly placed IRA among the offensive weapons of the United Front strategy, attracting and organizing non-Communist workers and peasants.

1 Rasshirennyi plenum ispolkoma Kommunisticheskogo Internatsionala (21 marta-6 aprelia 1925g.). Stenograficheskii otchet (Moskva, 1925), p. 578. Hereafter cited as Piatyi plenum.

2 Ibid., p. 579.

3 Ibid., pp. 445-446. 
Not only did the Fifth ECCI Plenum state unambiguously the use to be made of International Red Aid; it also suggested the value of auxiliary organizations in general. The Plenum was the first Comintern body to emphasize the usefulness of mass auxiliary or front organizations within the United Front strategy. The theses adopted by the Plenum defined the United Front simply; it was "the method of revolutionary agitation and organization of the masses - i.e., the correct approach of Communists toward the broad working mass in a given stage of the movement." 1 A primary means of reaching and enveloping these broad masses, the theses declared, was the "establishment of a whole series of auxiliary non-party organizations". ${ }^{2}$ As noted above, the Plenum unquestionably placed IRA in the category of auxiliary organizations mentioned in the theses.

The Fifth Plenum introduced the idea of expanding the use of auxiliary organizations, and the Sixth Plenum of the ECCI (during February and March 1926) elaborated upon the earlier suggestion. Its general resolution on the Communist movement demanded that "various forms of mass organizations be established in every country". The resolution continued, "Of the organizations already in existence, the work of IRA above all demands the support of Communists."3 The Sixth Plenum formed a special Commission on Mass Work, headed by the prominent Comintern figure, Otto Kuusinen. In his report for the Commission Kuusinen declared, "We must, so to speak, create a whole solar system of organizations and small committees around the Communist Parties." Kuusinen stressed the value of sympathetic, but non-Communist, organizations; International Red Aid was specified as an example. ${ }^{4}$

The system of fronts to which Kuusinen referred was described more fully in the resolution presented by his Commission, "On Methods and Forms of Organizationally Enveloping the Masses Drawn into the Sphere of Communist Influence". This document was probably the most important ever issued by the Comintern on the subject of front organizations. The special concern of the Kuusinen resolution was the type of body it described as the "sympathetic mass organization created to fulfill special tasks"; 5 International Red Aid was again named. Two

1 Rasshirennyi plenum ispolkoma Kominterna (21 marta-6 aprelia 1925g.): Tezisy i Rezoliutsii (Moskva-Leningrad, 1925), p. 15.

2 Ibid., p. 26.

s Shestoi (VI) rasshirennyi plenum ispolkoma Kominterna (17 fevralia-15 marta 1926g.). Stenograficheskii otchet (Moskva, 1927), p. 631.

4 Ibid., p. 486.

5 Ibid., pp. 646-647. An alternative approach to the task of organizing those who had fallen under Party influence was to infiltrate various existing non-Communist 
kinds of these sympathetic groups were identified according to their relationship with the Comintern: those "autonomously dependent" and those fully independent. ${ }^{1}$ Although none were given at the Plenum, examples of organizations "autonomously dependent" upon the Comintern would probably include the Communist Youth International and the International of Communist Women. International Red Aid, on the other hand, fell into the "independent" group; it was not to be considered an overtly Communist organization. ${ }^{2}$

If IRA was to be independent of the Comintern, how did the Comintern maintain control over the policies and activities of IRA? The resolution presented by Kuusinen's Commission answered this question most explicitly. All Communists in a "sympathetic mass organization" such as IRA were to organize themselves into a "fraction", especially in the central apparatus of the front. The activities of the fraction were to be conducted under the "political leadership of Party organs on the basis of instructions and directives of the ECCI". ${ }^{3}$ The great importance of this kind of Communist work was strongly emphasized:

"Every Communist Party member must be aware that fraction work in mass organizations [...] is also Party work, and for most members of the Party is even the most important part of their Party work."4

The leading fraction within International Red Aid was almost synonymous with the central apparatus, for Communists filled virtually all the key positions in the EC IRA; Marchlewski, Lepeshinsky, Tëmkin, Pestkowski, Kolarov, Treint, and many other leading figures were Party members. The leadership of IRA, firmly in the hands of its Communist faction, was directly responsible to the Party and the ECCI. Policies and decisions of the Red Aid central apparatus were thus subject to the approval of the Comintern apparatus, even though IRA as an organization was in no way formally tied to the Comintern.

The United Front strategy had been refined and strengthened when the ECCI during 1925 and early 1926 specified the place to be filled by International Red Aid and other "sympathetic mass organizations". The decision to employ IRA and similar fronts in the effort to influence

worker's groups, such as trade unions or cooperatives. Communists in such groups were to form "fractions" in order to concentrate their efforts on influencing the policies of the organization and winning support of non-Communist members.

1 Ibid., p. 647.

2 Ibid.

3 Ibid., p. 648.

4 Ibid., pp. 648-649. Emphasis in the original. 
and enlist the masses dictated that they would devote themselves above all else to agitation and propaganda. In the case of IRA the decisions of the ECCI, which concluded the controversy over how the front would be used, required that relief activities must be secondary to agitation and propaganda, although relief was definitely not abandoned. The resolution of the debate over purpose, defined by the Fifth and Sixth Plenums, also reflected the political struggle within the Soviet Union, for it reinforced the strategy against which Zinoviev had set himself. The controversy within International Red Aid concerning the utility of the organization helped to clarify the issues of dissension within IRA and the Comintern. In resolving that controversy, Comintern and Red Aid leaders revealed that IRA would serve international Communism as an offensive weapon of the United Front "from below".

\section{IV}

THE ACTIVITIES OF INTERNATIONAL RED AID

During its first four years International Red Aid actively distributed aid and poured out agitation and propaganda in increasing amounts. At the outset the organization was involved only with relief, but gradually agitprop work caught up with and even surpassed the aid activities. It was undoubtedly the steady growth of both aid and agitprop that had required the Comintern to decide in what capacity the rapidly expanding auxiliary would be of greatest use. The changing emphasis within IRA from relief to agitprop, especially after 1925, revealed in practical form the Comintern's decision that IRA would be a transmission belt connecting the Party with the unaffiliated masses.

Relief work continued throughout the history of IRA to be the organization's ostensible purpose, and the aid given political prisoners and exiles always provided the basic content of IRA agitprop. After the important Fifth and Sixth ECCI Plenums, however, the aid activities were subordinated to agitprop. It no longer mattered whether the prisoner or exile receiving aid actually benefitted, for now the focus shifted from the recipient to the donor. Seeking to exploit the maximum propaganda mileage from its generosity, International Red Aid made every effort to publicize the aid it rendered. IRA did not, of course, stop collecting and spending money for those "persecuted by bourgeois class justice"; the seemingly humanitarian values which these activities reflected gave the organization its most effective appeal to the unaffiliated masses.

According to IRA statistics, the organization spent at least 2.6 million dollars in three kinds of aid between 1923 and 1926. Well over 
half of this total went to political prisoners and their families in the form of direct material aid. The prisoners received cash, personal necessities, and discharge pay upon release from prison. Their families were given food, clothing, and money amounting from one to nine dollars per month, depending upon their situation and funds available. ${ }^{1}$ The second largest category of aid recipients were political emigrants, mostly Communists who fled to the Soviet Union in the face of probable arrest in their own countries. Before 1927 only MOPR USSR among the Red Aid sections gave any significant aid to political emigrants. Within the Soviet Union, however, all political emigrants were the responsibility of MOPR USSR after 1923.2 The Soviet section spent some $\$ 850,000$ on these emigrants, supplying them with shelter, medical care, political education, and jobs. ${ }^{3}$ The third major activity, legal defense, was conducted exclusively by sections other than MOPR USSR and was financed through the resources of each section involved. Sometimes the Red Aid section supplied a lawyer for the defendant, as in the case of the Scottsboro boys in Alabama; sometimes defendants were given legal advice and told to plead their own cases, always keeping in mind the class character of the bourgeois justice that they faced. By the end of 1926 legal aid had allegedly cost Red Aid sections over $\$ 350,000$.4

The various kinds of aid that IRA dispensed complemented the rapidly expanding activities of agitation and propaganda. One major category of Red Aid agitprop was printed material, which included both periodicals and pamphlets. Unfortunately it is impossible to determine exactly how much was published or how much was spent on the written word. However, by 1926 periodicals were appearing at various intervals in the United States, France, Germany, Great Britain, and several other states. In addition, numerous pamplets dealing with aspects of the "white terror" were pouring off the IRA presses in several countries. The Soviet Union undoubtedly produced the greatest volume of published agitprop, including three periodicals: MOPR, Biulleten' $T s k$ MOPR USSR, and Internatsional'naia Maiak. (The first two were primarily for functionaries, the third for the rank-and-file.)

Other than publishing, the most successful form of agitprop was the international campaign, introduced in the first quarter of 1925. The international campaigns were episodic in nature, unlike earlier Red Aid campaigns that had been annual affairs commemorating such revolution-

1 MOPR (January-February, 1926), p. 21; Biulleten' (March 29, 1927), p. 15.

2 Pervaia konferentsiia, p. 85.

${ }^{3}$ MOPR (January-February, 1926), p. 21; Biulleten' (January 31, 1926), p. 7 ;

(March 30, 1927), p. 15; (July 31, 1927), p. 2.

' Biulleten' (March 30, 1927), p. 14. 
ary anniversaries as May Day, November 7, and March 18. The new type of campaign might last several days, weeks, or even years. It was organized around a specific issue and continued until the issue was won or lost or until the campaign no longer could draw mass support. Most of the campaigns undertaken in 1925 were rather general in character, attacking the "white terror" in Rumania, Poland, Hungary, Bulgaria, and elsewhere, or agitating for general amnesty of political prisoners in Germany, France, and Britain. ${ }^{1}$

The more intensely conducted and apparently more effective campaigns revolved around specific examples of "bourgeois class justice". The first such campaign took place early in 1925, after a Communist named Lanzutski, a member of the Polish Parliament, was arrested on a charge of state treason and threatened with execution. The Lanzutski campaign was relatively limited, both in the number of sections involved and in the goals. One major aim seems to have been to gain adequate counsel for the defendant, and the British International Class War Prisoners Aid Society unsuccessfully sought to enlist the British Labour Party in this effort. The other important goal of the campaign was to organize the working class in support of Lanzutski, evoking a massive outcry against the Polish "White Terror". ${ }^{2}$ When Lanzutski eventually won aquittal in the Polish courts, full credit for his release was given to IRA by the Fifth Plenum of the ECCI. ${ }^{3}$ Perhaps it was the success of the Lanzutski campaign that encouraged the Executive Committee of IRA to embark upon more ambitious ventures of this type, for the number of international campaigns increased virtually every year from 1925 to 1931 . Six were conducted in 1925, forty-one in 1931, and a total of 138 during the seven years. ${ }^{4}$

In the agitation to free Nicola Sacco and Bartolemeo Vanzetti, the international IRA campaign came of age. Sacco and Vanzetti were condemned in 1921, accused of slaying the paymaster of a Massachusetts shoe factory. The movement to save their lives was begun at that time by American and European liberals and anarchists who believed that the evidence produced against the two Italian immigrants was insufficient to warrant conviction. IRA first took up the cause early in 1925 in co-operation with the American Sacco-Vanzetti Defense Committee. In 1926 IRA launched an independent campaign, attempting to depict

1 MOPR (January-February, 1926), p. 6.

2 Letter from N. Hannington to A. Henderson, March 23, 1925, Internationaal Instituut voor Sociale Geschiedenis, archives of the Labour and Socialist International, $2537 / 2$.

3 Piatyi plenum, p. 578.

4 Sputnik Moprovtsa (August, 1932), p. 32. 
itself as the leading defender of the oppressed in their struggle against "bourgeois class justice". 1

The methods of agitation and protest developed in this campaign exemplified the practical means by which IRA sought to envelop the broad masses and were adapted to most campaigns later conducted by IRA. In every country where the campaign was undertaken. "Committees of Defense" were set up. Formed on the initiative of the Red Aid section but including representatives of other organizations as well, these committees planned and directed a number of protest activities - demonstrations, petitions, picket lines, fund collections, and any other appropriate actions. A petition circulated in France in protest against the death sentence given Sacco and Vanzetti allegedly was signed by three million persons; rallies of protest in London were claimed to have drawn as many as twenty thousand sympathizers; letters and telegrams of protest sent to Governor Fuller of Massachusetts by individuals and organizations supposedly represented some fifty million persons. ${ }^{2}$

It is extremely difficult to determine wheter the Sacco-Vanzetti campaign accomplished the purposes for which it was designed. If the major objective had been merely to save the accused men's lives, the efforts of IRA obviously failed dismally. In fact, however, the lives of the two men counted for little; the ill fate of Sacco and Vanzetti became grist for the Red Aid propaganda mill. The struggle in their defense was undertaken primarily "to create even in the most backward masses a natural revulsion toward bourgeois class justice", ${ }^{3}$ a goal much too subjective to allow any rational appraisal of the degree to which it was achieved. A second purpose was to place IRA indisputably "at the head of the united movement of the toiling masses against the white terror". ${ }^{4}$ Progress toward attaining this end was perhaps evidenced, for the membership of IRA increased dramatically, especially outside the Soviet Union, during the course of the campaign. At the end of 1925 almost six million Red Aid members were claimed, and of these only one million $(20 \%)$ lived outside the USSR. Only two years later the total membership had swelled to eight million, of which about one-half were found in the "capitalist" world. ${ }^{5}$ The Sacco-Vanzetti campaign

1 Biulleten' (October 15, 1927), pp. 7-8.

2 Ibid., pp. 8-9.

3 Ibid., p. 7.

4 Ibid., p. 8.

5 MOPR (January-February, 1926), pp. 15-17; Biulleten' (February 15, 1928),

p. 1. A "reregistration" of Soviet Moprovsty was conducted during 1927, accounting for the decline in membership totals within the USSR. 
would seem to have helped IRA markedly to expand its influence among the "toiling masses".

The international campaigns provided IRA with an effective weapon of agitation and propaganda because they enabled the front to attach itself to emotional issues that were current, but the campaigns were by no means the only such weapon. Lectures were held, films shown, and concerts and plays staged by various sections in order to place the organization before a wide audience. ${ }^{1}$ In addition, the EC IRA in January 1925 created an agitprop (agitation and propaganda) department to which was given the responsibility of centralizing and coordinating "all work in the area of oral and written agitation and propaganda".2 Almost immediately the agitprop department of the EC IRA directed all Red Aid sections to form similar departments in their Central Committees. ${ }^{3}$

The Comintern apparatus by 1926 had determined that agitation and propaganda, the means by which IRA made contact with and attempted to gain influence over the masses, would become the central work of the organization. The activities of aid that had inspired creation of International Red Aid certainly were not ignored in 1926 or later; the ostensible and widely proclaimed purpose was still to "render material, moral, and legal aid to all victims of bourgeois class justice and the white terror". Prisoners and their families continued to receive money and gifts; political emigrants continued to be cared for; and defendants in political trials continued to have the benefit of Red Aid lawyers or legal counsel. The primary concern, however, was no longer the fate of the "victim", but rather creation of widespread sympathy for Communism, organized under the banner of International Red Aid.

International Red Aid, founded in 1922 primarily to dispense relief to incarcerated revolutionaries, by 1926 had been transformed into an organization to disseminate Communist propaganda under the allegedly non-partisan banner of creating "international solidarity" among the "toiling masses". This shift in purpose determined the character of the organization and its activities, as well as the relationship between it and the Comintern, at least until 1935. The changes in IRA also reflected significant and closely related trends in the Russian Communist Party and the Comintern, namely, the rapid decline of Zinoviev and the simultaneous final rejection of his aggressive revolutionary policy in favor of the more passive strategy of the United Front.

1 MOPR (September-October, 1926), p. 30.

'Biulleten' (January 31, 1925), pp. 7-8.

3 MOPR (September-October, 1926), p. 31. 
The year 1926 marked the emergence of International Red Aid as a recognized component of the total revolutionary strategy of the Comintern. Having already set up a sound organizational structure, IRA now began to refine its methods of reaching the non-Communist masses, i.e., its weapons of agitation and propaganda. The precise relationship between the Comintern and its auxiliary was also stated, a relationship in which IRA acted strictly according to the dictates of the Comintern, while carefully maintaining the fiction of independence. The years before $\mathbf{1 9 2 6}$ had molded International Red Aid to the needs of the Comintern; and after 1926 until its dissolution in 1943 IRA served its parent, faithfully executing every demand of Comintern policy. 